\title{
RESPON PERTUMBUHAN JAGUNG (Zea mays L.) TERHADAP PUPUK KANDANG DAN UREA PADA MEDIA PASIR
}

\section{RESPONSE OF MAIZE (Zea mays L.) GROWTH UNDER MANURE AND UREA FERTILIZER ON SAND MEDIA}

\author{
Fajrin Pramana Putra*, Nur Ikhsan, Milla Virdaus \\ Program Studi Teknologi Produksi Tanaman Perkebunan, Politeknik Lamandau \\ Jln. Trans Kalimantan Desa Kujan, Lamandau, Kalimantan Tengah, 74612 - Indonesia \\ *Korespondensi: fajrin.pramana.p@gmail.com
}

\begin{abstract}
ABSTRAK
Pasir dapat digunakan sebagai media tanam alternatif untuk menggantikan fungsi tanah namun banyak memiliki faktor pembatas dari rendahnya kandungan bahan organik dan rendahnya daya pegang air. Penggunaan pupuk kandang menjadi solusi perbaikan struktur tanah pasir sehingga meningkatkan kemampuan mengikat air meningkat, dan meningkatkan kadar bahan organik pada tanah pasir. Penelitian ini bertujuan untuk mengetahui respon pertumbuhan tanaman jagung pada media tanam pasir yang diberikan pupuk kandang dan urea. Penelitian ini dilaksanakan pada Oktober-November 2020 di kebun percobaan Politeknik Lamandau, Kabupaten Lamandau. Penelitian merupakan rancangan Faktorial dengan 2 perlakuan dengan 3 ulangan disusun secara Rancangan Acak Kelompok Lengkap (RAKL). Perlakuan pertama yaitu pupuk kandang dengan 2 taraf yaitu 0 ton ha-1 dan 20 ton ha-1. Perlakuan kedua dosis pupuk urea yang terdiri atas tiga taraf yaitu $200 \mathrm{~kg} \mathrm{ha}^{-1}, 300 \mathrm{~kg} \mathrm{ha}^{-1}$, dan $400 \mathrm{~kg} \mathrm{ha}^{-1}$. Hasil penelitian menunjukkan bahwa perlakuan pupuk kandang dan dosis pupuk urea berpengaruh secara nyata secara mandiri dan tidak ada interaksi antar perlakuan. Perlakuan dosis pupuk urea hanya mampu meningkatkan pertumbuhan jagung pada variabel tinggi tanaman pada dosis $200 \mathrm{~kg}$. ha-1. Perlakuan pemberian pupuk kandang 20 ton ha-1 mampu meningkatkan pertumbuhan jagung pada variabel tinggi tanaman, luas daun, bobot segar tanaman, dan bobot kering tanaman. Pemberian pupuk kandang 20 ton ha- ${ }^{-1}$ mampu memberikan bobot kering tanaman sebesar 20,50 g. Sedangkan yang tidak diberi pupuk kandang mengalami penurunan bobot kering sebesar $91,02 \%$.
\end{abstract}

Kata kunci: bobot kering tanaman, jagung, pasir, pupuk

\begin{abstract}
Sand is often used as an alternative planting medium to replace soil, but have limiting factors from the low content of organic matter and low water holding capacity. The use of manure is a solution to improve the structure of sand so that it increases the ability to hold capacity of water and increases the organic matter content in sand. This study aimed to determine the maize growth on sand media given manure and nitrogen fertilization. This research was conducted in on October November 2020 in the Politeknik Lamandau, Lamandau Regency. This study was a factorial design with 2 treatments and 3 replications with Randomized Complete Block Design (RCBD). The first treatment is manure with 2 levels consisting of 0 tons ha-1 and manure 20 tons ha-1. The second treatment was the dose of urea consisting of $200 \mathrm{~kg} \mathrm{ha}^{-1}, 300 \mathrm{~kg} \mathrm{ha}^{-1}$, and $400 \mathrm{~kg} \mathrm{ha}^{-1}$. The results showed that the manure treatment and the dose of urea were significantly independent and there was no interaction between treatments. Urea fertilizer dosage was only able to increase maize growth at a variable plant height at a dose of $200 \mathrm{~kg} \mathrm{ha}^{-1}$. The treatment of manure with a dose of 20 ton ha- ${ }^{-1}$ was able to increase maize growth on the variables of plant height, leaf area, crop fresh weight, and crop dry weight. Given of manure with a dose of 20 ton ha ${ }^{-1}$ was able to provide crop dry weight of $20.50 \mathrm{~g}$. Meanwhile, it was not to give manure experienced a decrease in crop dry weight by $91.02 \%$.
\end{abstract}

Keywords: crop dry weight, fertilizer, maize, sand 


\section{PENDAHULUAN}

Lahan berpasir merupakan media tanam yang bermasalah dan mempunyai banyak faktor pembatas bagi pertumbuhan tanaman. Tanah pasiran pada umumnya rendah kandungan bahan organiknya, sehingga cenderung memiliki struktur butir tunggal. Pasir memiliki kemampuan menahan lengas yang rendah karena sifat tanah yang porus, sehingga kandungan air yang tersedia pada tanah pasir dibawah kapasitas lapang, serta tingginya kecepatan infiltrasi 2,5-25 cm jam $^{-1}$ dibandingkan 0,001-0,1 cm jam $^{-1}$ pada tanah lempung (Putra, 2017; Yu et al., 2016).

Budidaya tanaman pada tanah pasir memiliki sejumlah kendala yaitu rendahnya sifat kimia, fisik, dan biologinya. Tekstur pasir yang kasar menyebabkan pemberian pupuk mudah terlindih atau leaching. Meskipun demikian, tanah berpasir dapat digunakan sebagai media alternatif yang dapat menggantikan fungsi tanah. Namun tanah berpasir memiliki pori-pori yang besar. Pelakuan penambahan bahan organik mampu memperbaiki sifat fisik tanah sehingga mampu menahan air dengan optimal. Penggunaan pupuk kandang di lahan kritis merupakan kebutuhan mutlak (Rajiman et al., 2008).

Pupuk kandang merupakan salah satu pupuk organik dan juga sebagai pembenah terbaik jika dibandingkan dengan bahan pembenah lainnya. Pupuk kandang dapat dimanfaatkan untuk menciptakan sistem pertanian yang ramah lingkungan dan mengurangi penggunaan pupuk anorganik. Beberapa fungsi pupuk kandang antara lain mampu membantu tanaman dalam penyerapan unsur hara, memperbaiki sifat fisik tanah, meningkatkan daya sanggah tanah terhadap perubahan $\mathrm{pH}$, dan menurunkan fiksasi $\mathrm{P}$ dan sebagai reservoir hara sekunder, serta sumber energi bagi mikroorganisme tanah untuk dekomposisi dan pelepasan unsur hara dalam ekosistem tanah (Sanchez, 2008; Mirsalin et al., 2018).

Manfaat pupuk kandang yakni dapat meningkatkan kandungan klorofil dan laju fotosintesis, menjadikan vigor tanaman lebih kuat, merangsang produksi cabang dan bunga serta buah, serta mengurangi gugurnya daun, bunga maupun bakal buah (Buntoro et al., 2014). Pada lahan pasir, bahan organik yang dibutuhkan akan lebih banyak dibandingkan pada lahan konvensional yakni sekitar 15 - 20 ton (Rajiman et al., 2008).

Selain pupuk kandang, tanaman juga membutuhkan berbagai unsur hara, salah satunya Nitrogen selama fase vegetatif. Nitrogen mendukung tanaman dalam memproduksi protein, lemak, karbohidrat, dan senyawa organik lainnya (Fahmi et al., 2010). Pupuk N merupakan pupuk yang paling dibutuhkan oleh tanaman karena termasuk dalam unsur hara makro. Nitrogen banyak sekali mengendalikan proses metabolisme pada tanaman terutama pada proses fotosintesis tanaman. Keberadaan unsur $\mathrm{N}$ sangat vital sehingga perlu penambahan unsur $\mathrm{N}$ pada setiap budidaya tanaman termasuk pada pada saat budidaya tanaman jagung (Aprilyanto et al., 2016).

Pada tanaman jagung memerlukan unsur hara untuk kelangsungan hidupnya. 
Dalam satu ton biji jagung tanaman jagung mampu menyerap 23-34 kg N; 6,5-11 kg $\mathrm{P}_{2} \mathrm{O}_{5}$, dan 14-42 $\mathrm{kg} \mathrm{K} \mathrm{K}_{2} \mathrm{O}$, pengelolaan hara diperlukan untuk memenuhi kebutuhan tanaman (Akil, 2013). Pada budidaya tanaman jagung, resiko kegagalan dapat lebih rendah dibandingkan dengan budidaya tanaman palawija lainnya. Selain itu umur panennya yang relatif cepat ratarata yaitu 60 \pm 70 hari setelah tanam sehingga memudahkan peneliti agar lebih cepat mengetahui hasilnya (Jurhana et al., 2017).

Atas dasar tersebut maka dilakukan penelitian mengenai adaptasi tanaman tanaman jagung erhadap media tanam pasir dengan perlakuan pemberian pupuk kandang dan urea dengan dosis berbeda. Tujuan penelitian ini yaitu untuk mengetahui mengetahui respon tanaman jagung pada media tanah pasir melalui penambahan pupuk kandang dan urea dengan dosis berbeda.

\section{BAHAN DAN METODE}

Penelitian dilaksanakan di kebun percobaan Politeknik Lamandau, Kabupaten Lamandau Provinsi Kalimantan Tengah. Penelitian dilaksanakan pada bulan Oktober 2020 hingga bulan november 2020. Analisa tanaman dilakukan di Laboratorium Tanaman Politeknik Lamandau. Alat yang digunakan terdiri dari timbangan digital, oven, cangkul, gunting, meteran, penggaris, polibag ukuran $3 \mathrm{~kg}$, dan kertas koran. Bahan yang digunakan terdiri dari benih jagung varietas Benih Jagung Manis, pasir, Urea, TSP, $\mathrm{KCl}$, dan pupuk kandang.
Penelitian menggunakan Rancangan Acak Kelompok Lengkap (RAKL) dengan 6 perlakuan dan 3 ulangan. Perlakuan yang dicobakan adalah $\mathrm{P} 0=$ tanpa pupuk kandang (0 ton ha-1, P1= dosis pupuk kandang20 ton ha-1. Perlakuan dosis pupuk urea sebagai berikut: $\mathrm{N} 1=$ dosis urea $200 \mathrm{~kg} \mathrm{ha}^{-1}, \mathrm{~N} 2=$ dosis urea $300 \mathrm{~kg} \mathrm{ha}^{-1}, \mathrm{~N} 3=$ dosis urea $400 \mathrm{~kg}$ ha $^{-1}$.

Pemeliharaan Tanaman meliputi pengendalian hama, penyiangan, dan penyiraman. Penyiraman rutin dilakukan setiap hari selama pertumbuhan tanaman yaitu pada pagi hari. Penyiangan dilakukan saat tanaman berumur 21 dan 40 HST.

Variabel pengamatan meliputi tinggi tanaman, luas daun tanaman, berat segar total tanaman, berat kering total tanaman. Data pengamatan dianalisis menggunakan sidik ragam dengan uji F a 5\%. Apabila terdapat perbedaan nyata diantara perlakuan maka dilanjutkan dengan Uji Duncan's Multiple Range Test (DMRT) a 5\%.

\section{HASIL DAN PEMBAHASAN}

\section{Tinggi Tanaman}

Pertambahan tinggi tanaman menunjukkan aktivitas pertumbuhan vegetatif suatu tanaman. Berdasarkan hasil sidik ragam menunjukkan bahwa pertumbuhan tinggi tanaman jagung dipengaruhi secara nyata oleh perlakuan pupuk urea dan pupuk kandang (Tabel 1).

Berdasarkan Tabel 1 perlakuan tanpa pupuk kandang diperoleh tinggi tanaman 22,28 cm sedangkan perlakuan menggunakan pupuk kandang yaitu 58,24 cm. Hal ini menunjukkan bahwa pupuk 
kandang memberikan respon positif bagi pertumbuhan tinggi tanaman. Pemberian bahan organik berupa pupuk kandang sapi memperbaiki struktur tanah, kemantapan agregat tanah, daya menahan air, permeabilitas, pengharaan, aerasi, dan perkembangan akar (Rajiman, 2014).

Tabel 1. Tinggi tanaman jagung

\begin{tabular}{|c|c|c|c|c|}
\hline \multicolumn{5}{|c|}{ Tinggi Tanaman $(\mathrm{cm})$} \\
\hline \multirow{2}{*}{$\begin{array}{c}\text { Perlakuan } \\
\text { Pupuk Kandang }\end{array}$} & \multicolumn{3}{|c|}{ Dosis Pupuk Urea } & \multirow[t]{2}{*}{ Rerata } \\
\hline & $200 \mathrm{~kg} \mathrm{ha}^{-1}$ & $300 \mathrm{~kg} \mathrm{ha}^{-1}$ & $400 \mathrm{~kg} \mathrm{ha}^{-1}$ & \\
\hline 0 ton ha-1 & 26,41 & 20,19 & 20,25 & $22,28 \mathrm{~b}$ \\
\hline 20 ton ha-1 & 69,03 & 52,24 & 53,46 & $58,24 \mathrm{a}$ \\
\hline Rerata & $47,72 \mathrm{a}$ & $36,22 \mathrm{~b}$ & $36,85 \mathrm{~b}$ & $(-)$ \\
\hline
\end{tabular}

Keterangan: huruf yang berbeda pada baris dan/atau kolom yang sama menunjukkan perbedaan yang nyata $(P<0,05)$.

Pupuk kandang sapi merupakan sumber bahan organik yang mengandung nitrogen $(\mathrm{N})$ 1,05\%, fosfor (P) 0,5\%, kalium (K) 0,73\%, magnesium (Mg) 0,13\%, Ca 0,11\%, dan Fe 7.569 ppm, pH 6,5 (Musofie, 2008). Dalam perombakan bahan organik akan dilepas mineral-mineral hara tanaman $\mathrm{N}, \mathrm{P}, \mathrm{K}, \mathrm{Ca}, \mathrm{Mg}$, dan $S$, serta hara mikro dalam jumlah yang relatif kecil (Syukur, 2005; Yuwono, 2009). Sehingga berdasarkan hal tersebut, pemberian pupuk kandang mampu memperbaiki sifat fisik dan sifat kimia tanah pasir, pada akhirnya akan memberikan dampak positif bagi pertumbuhan tinggi tanaman jagung. Berdasarkan penelitian Nurhayati et al. (2013) menyebutkan bahwa dengan pemberian pupuk kandang sapi mampu meningkatkan pertumbuhan tinggi tanaman pada tanaman wijen di lahan pasir.

Kemudian berdasarkan dosis pupuk Urea yang diberikan terlihat bahwa dengan dosis 200 $\mathrm{kg} \mathrm{ha}^{-1}$ mampu memberikan hasil pertumbuhan tinggi tanaman yang baik dibandingkan dosis pupuk urea yang lainnya. Titah \& Purbopuspito (2016) menyatakan bahwa unsur hara yang diberikan akan mempengaruhi dalam meningkatkan pertumbuhan tanaman. Pupuk urea merupakan kunci utama dalam usaha meningkatkan pertumbuhan tanaman jagung manis, absorpsi $\mathrm{N}$ yang terkandung dalam pupuk urea berlangsung pada fase vegetatif maka proses fotosintesis akan berjalan aktif, sehingga proses pembelahan sel akan berjalan lancar (Faqih et al., 2019; Fahmi et al., 2010).

Namun, pada saat pemberian pupuk urea dengan dosis yang tinggi maka akan menghambat pertumbuhan tinggi tanaman. Yanti et al. (2014) menyatakan bahwa pemberian pupuk urea dengan dosis optimum akan memberikan pertumbuhan yang optimal, namun pada saat diberikan dosis pupuk urea melebihi optimum akan menghambat pertumbuhan tanaman yang digambarkan secara kurva kuadratik.

\section{Luas Daun}

Berdasarkan Tabel 2 bahwa perlakuan pemberian pupuk kandang memberikan pengaruh yang nyata terhadap pertumbuhan luas daun tanaman jagung. Tabel 2 menunjukkan bahwa pada perlakuan dengan pupuk kandang menghasilkan luas daun $394,31 \mathrm{~cm}^{2}$ dan lebih luas daripada 
perlakuan tanpa pemberian pupuk kandang yakni 131,53 $\mathrm{cm}^{2}$. Hal ini dapat diduga karena adanya pengaruh pemberian pupuk kandang yang mampu memperbaiki sifat fisik dan kimia tanah pasir sehingga mampu membantu dalam meningkatkan pertumbuhan luas daun tanaman jagung di media pasir.

Tabel 2. Luas daun jagung

\begin{tabular}{|c|c|c|c|c|}
\hline \multicolumn{5}{|c|}{ Luas daun $\left(\mathrm{cm}^{2}\right)$} \\
\hline \multirow{2}{*}{$\begin{array}{c}\text { Perlakuan } \\
\text { Pupuk Kandang }\end{array}$} & \multicolumn{3}{|c|}{ Dosis Pupuk Urea } & \multirow{2}{*}{ Rerata } \\
\hline & $200 \mathrm{~kg} \mathrm{ha}^{-1}$ & $300 \mathrm{~kg} \mathrm{ha}^{-1}$ & $400 \mathrm{~kg} \mathrm{ha}^{-1}$ & \\
\hline 0 ton ha-1 & 145,31 & 126,77 & 122,50 & $131,53 \mathrm{~b}$ \\
\hline 20 ton ha-1 & 352,71 & 377,19 & 453,02 & $394,31 \mathrm{a}$ \\
\hline Rerata & $249,01 \mathrm{a}$ & $251,98 \mathrm{a}$ & $287,76 \mathrm{a}$ & $(-)$ \\
\hline
\end{tabular}

Keterangan: huruf yang berbeda pada baris dan/atau kolom yang sama menunjukkan perbedaan yang nyata $(P<0,05)$.

Manfaat pupuk kandang yang mampu mengecilkan pori tanah pasir dan menghambat lolosnya unsur hara karena proses leaching pada tanah pasir sehingga mampu memberikan kebutuhan tanaman terhadap unsur-unsur hara bagi pertumbuhan tanaman. Saat daun tanaman jagung tumbuh dengan baik maka proses fotosintesis juga akan baik, sehingga akan memberikan hasil fotosintesis berupa fotosintat yang akan didistribusikan keseluruh tubuh tanaman untuk proses pembelahan sel dan pertumbuhan biomasa tanaman.

Hasil sidik ragam menunjukan bahwa penggunaan dosis pupuk urea pada perlakuan $400 \mathrm{~kg} \mathrm{ha}^{-1}$ menunjukan pengaruh yang nyata $(\mathrm{p}<0,05)$ dibandingkan dengan perlakuan lainnya terhadap luas daun tanaman jangung. Dengan tersedianya $\mathrm{N}$ yang tinggi bagi tanaman akan mendorong pertumbuhan vegetatif terutama pertumbuhan daun tanaman. Pupuk urea pada tanaman berfungsi dalam memperluas area daun sehingga dapat meningkatkan fotosintesis. Semakin tinggi pemberian dosis pupuk urea (sampai batas optimum-nya) maka jumlah klorofil yang terbentuk akan meningkat (Pramitasari et al., 2016). Selain dipengaruhi oleh jumlah daun, luas daun berperan penting dalam penyediaan fotosintat. Daun yang lebar memiliki potensi menghasilkan fotosintat yang lebih tinggi dibandingkan dengan daun sempit. Ketersediaan hara Nitrogen dengan jumlah yang optimal akan mempengaruhi proses fotosintesis dengan berjalan aktif, sehingga pembelahan, pemanjangan dan diferensiasi sel akan berjalan dengan baik (Kogoya et al., 2018).

\section{Bobot Segar Tanaman}

Berdasarkan Tabel 3 bahwa pada perlakuan pemberian pupuk kandang menujukan pengaruh nyata terhadap bobot segar tanaman jagung. Tabel 3 menunjukkan bahwa perlakuan dengan menggunakan pupuk kandang mampu memberikan bobot segar tanaman yang lebih baik dibandingkan dengan tanpa diberikan pupuk kandang yakni sebesar 36,15 g. Bobot segar tanaman jagung meningkat 7,8 kali lipat jika diberikan pupuk kandang pada media pasir. 
Tabel 3. Bobot segar tanaman

\begin{tabular}{|c|c|c|c|c|}
\hline \multicolumn{5}{|c|}{ Bobot segar tanaman (g) } \\
\hline \multirow{2}{*}{$\begin{array}{c}\text { Perlakuan } \\
\text { Pupuk Kandang }\end{array}$} & \multicolumn{3}{|c|}{ Dosis Pupuk Urea } & \multirow{2}{*}{ Rerata } \\
\hline & $200 \mathrm{~kg} \mathrm{ha}^{-1}$ & $300 \mathrm{~kg} \mathrm{ha}^{-1}$ & $400 \mathrm{~kg} \mathrm{ha}^{-1}$ & \\
\hline 0 ton ha $\mathbf{h}^{-1}$ & 5,11 & 3,99 & 4,80 & $4,63 \mathrm{~b}$ \\
\hline 20 ton ha-1 & 41,84 & 34,72 & 31,91 & $36,15 \mathrm{a}$ \\
\hline Rerata & $23,47 \mathrm{a}$ & $19,36 \mathrm{a}$ & $18,35 \mathrm{a}$ & $(-)$ \\
\hline
\end{tabular}

Keterangan: huruf yang berbeda pada baris dan/atau kolom yang sama menunjukkan perbedaan yang nyata $(P<0,05)$.

Keadaan air di dalam jaringan tanaman akan mempengaruhi terhadap bobot segar tanaman dan juga dipengaruhi oleh kondisi lengas tanah pada media pasir (Faqih et al., 2019). Berdasarkan pernyataan ini diduga media pasir yang ditambahkan dengan pupuk kandang mampu mempertahankan kondisi lengas tanah yang ideal bagi tanaman jagung dibandingkan pada media pasir tanpa pupuk kandang sehingga berpengaruh terhadap bobot segar tanaman yang diamati karena kandungan air pada tanaman dipengaruhi oleh ketersediaannya pada media tanam

\section{Bobot Kering Tanaman}

Bobot kering tanaman merupakan jumlah biomassa dari suatu tanaman yang dicirikan dengan bertabahnya bobot tanaman hasil asimilasi oleh karbondioksida saat tanaman tumbuh dan berkembang (Buntoro et al., 2014). Hasil sidik ragam menunjukkan bahwa perlakuan pupuk kandang berpengaruh nyata $(P<0,05)$ terhadap berat kering total (Tabel 4). Sedangkan hasil sidik ragam pada perlakuan pemberian dosis pupuk nitrogen tidak menunjukkan pengaruh yang nyata.

Tabel 4. Bobot kering tanaman

\begin{tabular}{|c|c|c|c|c|}
\hline \multicolumn{5}{|c|}{ Bobot kering tanaman (g) } \\
\hline \multirow{2}{*}{$\begin{array}{c}\text { Perlakuan } \\
\text { Pupuk Kandang }\end{array}$} & \multicolumn{3}{|c|}{ Dosis Pupuk Urea } & \multirow{2}{*}{ Rerata } \\
\hline & $200 \mathrm{~kg} \mathrm{ha}^{-1}$ & $300 \mathrm{~kg} \mathrm{ha}^{-1}$ & $400 \mathrm{~kg} \mathrm{ha}^{-1}$ & \\
\hline 0 ton ha $\mathbf{a}^{-1}$ & 2,25 & 1,85 & 1,41 & $1,84 \mathrm{~b}$ \\
\hline 20 ton ha-1 & 23,91 & 18,93 & 18,67 & $20,50 \mathrm{a}$ \\
\hline Rerata & $13,08 \mathrm{a}$ & $10,39 \mathrm{a}$ & $10,04 \mathrm{a}$ & $(-)$ \\
\hline
\end{tabular}

Keterangan: huruf yang berbeda pada baris dan/atau kolom yang sama menunjukkan perbedaan yang nyata $(P<0,05)$

Bobot kering tanaman jagung menggunakan yang menggunakan pupuk kandang lebih tinggi dibandingkan tanpa pupuk kandang. Pada pemberian pupuk kandang mampu membentuk bobot kering tanaman sebesar 20,50 g, sedangkan jagung yang tidak diberi pupuk kandang mengalami penurunan bobot kering sebesar 91,02\% dibandingkan dengan jagung yang diberikan pupuk kandang.
Hal ini dapat diduga karena ketersediaan unsur hara dan air dalam tanah pasir yang diberi pupuk kandang. Pupuk kandang mampu menahan kehilangan unsur hara dan air dalam tanah pasir akibat pencucian dan penguapan. Selain itu pupuk kandang juga mampu menahan kehilangan air pada media pasir, sehingga air menjadi tersedia dan digunakan sebagai bahan utama untuk 
proses fotosintesis dan menghasilkan bahan kering sebagai pembentuk bobot kering tanaman (Buntoro et al., 2014).

\section{KESIMPULAN}

Perlakuan pemberian pupuk kandang di tanah pasir mampu meningkatkan pertumbuhan jagung. Variabel pertumbuhan jagung yang meningkat akibat penambahan pupuk kandang pada jagung adalah tinggi tanaman, luas daun, bobot segar tanaman, dan bobot kering tanaman. Perlakuan pemberian pupuk kandang sebesar 20 ton ha-1 mampu membentuk bobot kering tanaman sebesar 20,50 g. Jagung yang tidak diberikan pupuk kandang mengalami penurunan berat kering tanaman sebesar 91,02\% dibandingkan dengan yang diberikan pupuk kandang. Sedangkan perlakuan pemupukan nitrogen hanya mampu meningkatkan pertumbuhan tinggi tanaman, yaitu pada dosis $200 \mathrm{~kg} \mathrm{ha}^{-1}$.

\section{References}

Akil, M. (2013). Kebutuhan hara N, P, dan K tanaman jagung hibrida pada lahan kering di Kabupaten Gowa. Seminar Nasional Serealia.

Aprilyanto, W., Baskara, M., \& Guritno, B. (2016). Pengaruh populasi tanaman dan kombinasi pupuk N, P, K pada produksi tanaman jagung manis. Jurnal Produksi Tanaman, 4(6), 438-446.

Buntoro, B. H., Rogomulyo, R., \& Trisnowati, S. (2014). Pengaruh takaran pupuk kandang dan intensitas cahaya terhadap pertumbuhan dan hasil temu putih (Curcuma zedoaria L.). Vegetalika, 3(4), 29-39. DOI: 10.22146/veg.5759.

Faqih, A., Dukat, \& Trihayana. (2019). Pengaruh dosis dan waktu aplikasi pupuk urea terhadap pertumbuhan dan hasil tanaman jagung manis (Zea Mays Var. Saccharata Sturt) kultivar Bonanza F1. Jurnal
AGROSWAGATI, 7 (1), 18-28. DOI: http://dx.doi.org/10.33603/agroswag ati.v7i1.2846.

Fahmi, A., Syamsudin, S., Utami, N. H., \& Radjagukguk, B. (2010). Pengaruh interaksi hara Nitrogen dan Fosfor terhadap pertumbuhan tanaman jagung (Zea Mays L) pada tanah regosol dan latosol. Berita Biologi, 10 (3), 297-304. DOI: 10.14203/beritabiologi.v10i3.744.

Jurhana, Made, U., \& Madauna, I. (2017). Pertumbuhan dan hasil tanaman jagung manis (Zea mays Saccharata) pada berbagai dosis pupuk organik. J. Agrotekbis, 5 (3), 324-328.

Mirsalin, I., Mysatami, M. K., \& Ali, A. (2018). Pengaruh penggunaan pupuk organik mikroorganisme lokal media nasi, batang pisang, dan ikan tongkol terhadap pertumbuhan tanaman sawi (Brasicca juncea). Jurnal Biotek 6(1), 32-42. DOI: 10.24252/jb.v6i1.5127.

Musofie, A. (2008). Upaya pengembangan usaha tani di lahan pasir pantai melalui pemanfaatan limbah usaha peternakan, Makalah Seminar Nasional FTP-UGM.

Nurhayati, D. R., Sarwono, A. E., \& Hariyono, B. (2013). Pengaruh pupuk organik dan anorganik terhadap produksi dan kandungan minyak wijen serta kelayakan usaha tani di lahan pasir pantai. Buletin Tanaman Tembakau, Serat \& Minyak Industri, 5(1), 31-39. DOI:

http://dx.doi.org/10.21082/bultas.v5 n1.2013.31-39.

Putra, F. P., (2017). Pertumbuhan dan hasil tanaman serta komposisi gulma di berbagai proporsi populasi pada sistem tumpangsari padi gogo+kedelai di lahan pasir pantai. Thesis. Fakultas Pertanian. Universitas Gadjah Mada, Yogyakarta.

Pramitasari, H. E., Wardiyati, T., \& Nawawi, M. (2016). Pengaruh dosis pupuk Nitrogen dan tingkat kepadatan tanaman terhadap pertumbuhan dan hasil tanaman kailan (Brassica Oleraceae L.). Jurnal Produksi 
Tanaman, 4(1), 49 - 56. DOI: 10.21176/protan.v4i1.259.

Rajiman, Yudono, P., Sulistyaningsih, E., \& Hanudin, E. (2008). Pengaruh pembenah tanah terhadap sifat fisik tanah dan hasil bawang merah pada lahan pasir pantai Bugel Kabupaten Kulon Progo. J. Agrin. 12(2008), 67-77.

Rajiman. (2014). Pengaruh bahan pembenah tanah di lahan pasir pantai terhadap kualitas tanah. Prosiding Seminar Nasional Lahan Suboptimal: 147-154.

Sanchez, P. A. (2008). Properties and management of soil in the tropic soil organic matter. New York: John Wiley and Sons. 5: 225-270

Syukur, A. (2005). Pengaruh pemberian bahan organik terhadap sifat-sifat tanah dan pertumbuhan caisim di tanah pasir pantai. Jurnal Ilmu Tanah dan Lingkungan, 5(1), 30-38.

Kogoya, T., Dharma, I. P., \& Sutedja, I. N. (2018). Pengaruh pemberian dosis pupuk urea terhadap pertumbuhan tanaman bayam cabut putih (Amaranthus tricolor L.). EJurnal Agroekoteknologi Tropika, 7(4):575-584
Titah, J., \& Purbopuspito, J. (2016). Respon pertumbuhan jagung terhadap pemberian pupuk NPK, Urea, SP-36, dan KCl. Eugenia, 22 (2), 62-69. DOI: https://doi.org/10.35791/eug.22.2.20 16.12957.

Yanti, S. E. F., Masrul, E., \& Hannum, H. (2014). Pengaruh berbagai dosis dan cara aplikasi pupuk urea terhadap produksi tanaman sawi (Brassica juncea L.) pada tanah inceptisol Marelan. Jurnal Onaline Agroekoteknologi, 2(2), 770-780. DOI: 10.32734/jaet.v2i2.7165.

Yuwono, N. W. (2009). Membangun kesuburan tanah di lahan marginal. Jurnal Ilmu Tanah dan Lingkungan, 9 (2), 137-141.

Yu, J., Zhan, C., Li, Y., Zhou, D., Fu, Y., Chu, X., Xing, Q., Han, G., Wang, B., Guan, B., \& Wang, Q. (2016). Distribution of carbon, nitrogen and phosphorus in coastal wetland soil related land use in the Modern Yellow River Delta. Sci. Rep. 6(2016), 1-9. DOI:10.1038/srep37940. 